\title{
Disease Prevention with a Plant-based Lifestyle
}

\author{
Sabina V. Vyas \\ Public Health Consultant Chronic disease prevention through plant-based \\ nutrition. California, United States
}

\section{Introduction}

Animal experiments are commonly conducted to understand human diseases and responses to treatment. As decades of research indicate, the use of nonhuman animals (hereinafter referred to as animals) to translate the side effects, benefits, and impact of medications and treatments on the human body has been demonstrated to be ineffective; while billions of animals and humans have suffered (Shanks, Greek and Greek, 2009). Due to misleading safety and efficacy data from animal experiments, humans are often prescribed medications that may not be as effective or as safe as the patient, or even physician, may have been led to believe (Akhtar, 2015).

In the United States alone, over 820,000 animals were used for research in 2016. This number does not include many species, including mice, rats and aquatic animals, under the Animal Welfare Act (United States Department of Agriculture, USDA, 2017). It is estimated that up to 100 million mice and rats are used for research purposes in the us each year (Carbone, 2004). A number of species of farm animals are also used in research for the purpose of enhancing the agricultural industry. However, from an ethical standpoint, experimenting on animals subjects them to cruelty, costs billions of dollars a year, and often does not provide sufficient results to ensure human safety (Akhtar, 2015). A major reason that animal studies are ineffective is that human bodies are very different physiologically from other animals, including the way we develop diseases and how we absorb nutrients. Many advances have been made to create alternatives to animal testing, which are being adopted by scientists interested in innovative methods in research; and, yet, the use of animals for therapeutic testing is on the rise. To attain more accurate data regarding human health, there are no substitutes for human population- and clinical studies, particularly for lifestyle-related diseases, which may not be relevant to non-humans. This chapter addresses how we can make decisions towards disease prevention and reduce the demand for prescription drugs and, in turn, reduce animal research and testing, through the adoption of a whole foods, plant-based diet, which has

(C) SABINA V. VYAS, 2019 | DOI:10.1163/9789004391192_005

This is an open access chapter distributed under the terms of the prevailing CC-BY-NC License at the time 9004391192 of publication. 
demonstrated to minimize and, in some cases reverse, lifestyle-related disease. The chapter focuses on conditions that can be preventable, where medication is avoidable, as opposed to conditions that require management with medical intervention.

\section{The Unwanted Effects of Prescription Drugs}

The use of medications to treat human diseases, while often a necessity, can also lead to a range of complications. About 4.5 million outpatient and emergency visits occur in the us each year for adverse drug reactions (Sarkar et al., 2011). Of those who are hospitalized, an additional 840,000 patients are given drugs that cause serious adverse reactions during their hospital stay (Light, 2014). In total, about 2.74 million Americans are impacted by complications from prescription drugs each year, and this does not account for the impact of over-the-counter medications (Light, 2014). Even proper use of prescription drugs may lead to death. The European Commission estimates that adverse reactions from prescription drugs cause almost 200,000 deaths a year in Europe (Light, 2014). In the Us, an average of 128,000 deaths occur from properly prescribed medications annually. Combined, around 328,000 patients, in the Us and Europe, die from properly prescribed prescription drugs each year (Light, 2014).

The global rise in chronic diseases has resulted in an increase in the research, development, and testing of prescription medication to address and stabilize conditions, such as type 2 diabetes, cancer, and heart disease. The Centers for Disease Control and Prevention (CDC) describes chronic diseases and conditions (e.g., heart disease, stroke, cancer, type 2 diabetes, obesity, and arthritis), among the most common, costly, and often preventable health issues in the Us (CDC, 2017a). The rise in new prescription drugs on the market and increased consumption, due to an increase in lifestyle-related diseases, has resulted in an increase in animal research and testing. For example, according to the us Food and Drug Administration (FDA), new treatments are studied on laboratory animals to first determine potential toxicity before they can be tried on humans (FDA, 2014). These experiments identify side effects and the impact of medications on animals, but do not produce a complete or accurate translation of the medication's function and reaction in humans, including their effectiveness, toxicity, and side effects. Many people with chronic diseases take prescription drugs to better manage their conditions and achieve a better quality of life, although prescription drugs, especially for chronic conditions, often do not cure diseases or address their root causes. Prescription drugs are typically intended to alleviate symptoms or slow the advancement of a disease, and they may 
even prolong life, but their side effects may require additional medications that can negatively impact patients' quality of life. Prescription medications can also lead to dependency and drug overdoses (National Institute on Drug Abuse, 2017). In the us alone, there has been a spike in opioid use and dependency, and among 47,055 drug related deaths in 2014, 28,647 (60.9\%) involved an opioid (Rudd et al., 2016).

\section{3}

\section{The Cost of Chronic Disease}

While prescription drugs can prolong and improve patients' quality of life, they also lead to rising costs for patients and public healthcare systems. The United Kingdom (UK) spends £446 million, annually, of its National Health Service (NHS) budget on adverse drug reactions (Specialist Pharmacy Service, 2014). Unlike the UK, the Us government does not provide a universal healthcare coverage plan, though it spends substantial funds towards healthcare. US residents with multiple chronic conditions often face extensive out-of-pocket costs for their care, including higher costs for prescription drugs (CDC, 2016a). The high cost of multiple prescriptions, paired with undesirable side effects and reduced quality of life, is a common issue among those living with chronic diseases. Our aging population is growing and the prevalence of risk factors, such as poor diet, obesity, and inactivity, are contributing factors to the prevalence of multiple chronic conditions in young people, adults, and the elderly. Obesity is among the top risk factors, mainly because it is directly linked to conditions, such as heart disease, stroke, type 2 diabetes, and certain types of cancer; these conditions are among the leading causes of preventable death and the most expensive to conditions treat (CDC, 2017a). Globally, we are facing an obesity epidemic; $36 \%$ of the world's population is overweight or obese (The GBD 2015 Obesity Collaborators, 2017). In the US, $70.7 \%$ of the adult population, 20 years and older, is either overweight or obese; and $37.9 \%$ are obese (CDC, 2017a, 2017c).

The burden of multiple chronic conditions affects 1 in 4 Americans, and that number increases to 3 in 4 over the age of 65 (CDC, 2016a). Treating chronic diseases, mental health, and associated high risk behaviors, accounts for $86 \%$ of the us government's $\$ 2.7$ trillion annual healthcare expenditures (CDC, 2017b). The us government spends more on healthcare than any other developed country, yet they experience the lowest life expectancy (Commonwealth Fund, 2015). A recent epidemiological study of the eating habits of more than 536,00o people linked meat consumption with increased death rates from nine major diseases, including cancer, heart disease, respiratory 
diseases, stroke, diabetes, kidney disease, and liver disease (Etemadi et al., 2017). We should invest more funding and resources in a national, comprehensive, chronic disease-prevention approach and address policy, including corporate policies, to improve food creation and distribution standards, systems, and environments. It is with such changes that we can impact the masses and see a decline in new incidences of chronic diseases. Focusing on preventive medicine would allow for further research and application of human-relevant non-animal testing methods, since many chronic conditions that require treatment are influenced by human lifestyle choices. Research on the treatment of lifestyle-related conditions needs to focus on the human and the human lifestyle to be more effective. This focus could lead to a reduced demand for new lifestyle medications and may allow for greater application of innovative, non-animal methods in disease research and testing, consequently, reducing the number of animals used in these experiments. The concept of personalized medicine relies on the fact that humans are different from animals, and we need to rely on human-based research, using predictive human-based testing models, to tailor medicine effectively to the human population (Greek, Menache and Rice, 2012). It is possible to adopt a diet that benefits the health of humans and reduces or avoids the suffering of animals, including animals killed for consumption, animals involved in agricultural research, and animals used for research and testing of drug interventions and diseases. A whole food, plant-based diet, free from animal products, has been shown to be the most nutritious for our health; while it simultaneously avoids animal suffering and improves the sustainability of our environment and the planet.

\section{$4 \quad$ Why Eat a Plant-based Diet?}

\subsection{Health}

An abundance of research indicates that a whole foods, plant-based diet is effective in preventing and, in some cases, reversing chronic diseases. The us's Academy of Nutrition and Dietetics states that appropriately planned vegetarian and vegan, diets can be healthful and nutritionally adequate and may provide health benefits for the prevention and treatment of certain diseases (Melina, Craig and Levin, 2016). The British Association of Dietetics aligns with this statement, and states that a well-planned vegan diet supports healthy living for all ages and stages, including pregnancy, lactation, infancy, childhood, adolescence, older adulthood; and for athletes (British Dietetic Association, 2017; Melina, Craig and Levin, 2016). Eating a plant-based diet can help reduce the risk of, and possibly prevent, chronic conditions, such as ischemic heart 
disease, type 2 diabetes, hypertension, certain types of cancer, and obesity (Melina, Craig and Levin, 2016). Research in this field has not gone unnoticed, and the us's largest managed care organization, Kaiser Permanente, recommends healthy eating in the form of a plant-based diet, as the first line of treatment against chronic diseases (Tuso, Ismail and Bartolotto, 2013). According to Kaiser Permanente, this diet should include plant foods in their whole form, especially vegetables, fruits, legumes, and seeds and nuts (in smaller amounts). For the greatest health benefits, this diet limits or eliminates animal products. Total fats, such as oils, are generally restricted (Tuso, Ismail and Bartolotto, 2013). In summary, to achieve optimum health whole, plant-based foods are encouraged, while meats, dairy, eggs, and all refined processed foods (including refined sugars) are discouraged. Similarly, the American Medical Association has called for the availability of healthful plant-based meals in schools, food assistance programs, and hospitals. They request that hospitals across the us reduce the availability of sugar-sweetened beverages and eliminate processed meats, in addition to including plant-based meals to improve the health of patients, staff, and visitors (Berg, 2017).

\subsection{Antibiotic Resistance}

An additional health concern associated with consumption of animals and their products, is antibiotic resistance. Animals raised in factory farms are often treated with sub-therapeutic antibiotics to promote growth or reduce the spread of infections among animals, due to the high concentration of animals in confined spaces. Long periods of exposure to antibiotics in animals may lead bacteria to become resistant and survive, and there is strong evidence that antibiotic use in animal livestock can lead to resistant infections in humans (CDC, 2016b). Furthermore, large numbers of animals are used for research and testing of antibiotic resistance, contributing to the number of animals affected by human lifestyle choices. Over 400,000 American residents become ill from antibiotic-resistant foodborne bacteria every year (CDC, 2016d). The top five pathogens that result in hospital stays in the us are salmonella, norovirus, campylobacter, Toxoplasma, and E. coli (CDC, 2016c). Antibiotic resistance is at the forefront of public health issues because it makes illnesses, which were once easily treated with antibiotics, more difficult to cure and more expensive to treat (CDC, 2016b). Humans can contract these infections in a number of ways: (1) Consuming contaminated meat could lead to an infection in humans; (2) Bacteria contaminants in the environment via infected stool can spread to produce through irrigated contaminated water; or (3) Bacteria can contaminate our water supply (CDC, 2016b). All animals carry bacteria in their intestines, and when they are slaughtered, these bacteria can contaminate meat or other animal products, whether antibiotic resistant bacteria or not (CDC, 
2016b). Antibiotic resistant bacteria from animals can also contaminate nonanimal produce but using care, by washing your hands and produce prior to consuming it, can reduce your risk of food borne illness (Us Department of Health and Human Services, n.d.).

Eating health-promoting foods along with physical activity and stress management can help lead to overall well-being. Healthy eating and physical activity both contribute to keeping us healthy, and it is important to remember that while both are crucial, physical activity cannot undo the effects of a poor diet (Malhotra, Noakes and Phinney, 2015). Mental and emotional health are also important to our overall well-being and eating a diet rich in plants may play a role in accomplishing this balance. Research has shown that a plant-based diet not only reduces the risk of chronic diseases but also helps to boost overall mood and reduce anxiety, depression, and fatigue (Agarwal et al., 2015). Choosing to consume more plant-based foods can positively impact your health, both physically and mentally.

\subsection{Animals in Our Food System}

Eating a plant-based diet can also help reduce the contraction of illnesses caused by animal consumption while reducing harm to animals. While millions of animals are harmed each year from animal experimentation, in 2008, it was estimated that over 66 billion land animals were killed globally each year for human consumption (Food and Agriculture Organization of the United Nations, 2014). Farmed animals are not only used for human consumption; many are subject to experimentation under the premise of increasing production and the effectiveness of their use for human consumption (USDA Agricultural Research Service, n.d.). The findings from these experiments are intended to maximize products or outputs from these animals, which can lead to additional animal suffering due to the increased burden. Approximately us $\$ 1.4$ billion was spent on American agricultural animal research in 2016; Us \$9oo million in public funds and us $\$ 500$ million by private industry (Keen, 2019, Chapter 10 in this Volume).

To meet the demand for human consumption, billions of animals are raised on industrial factory farms or Concentrated Animal Feeding Operations (CAFOS), and the land area where animals congregate is often amongst feed, manure and urine, dead animals, and production operations (USDA National Resources Conservation Services, n.d.). CAFOs often lack direct sunlight and restrict movement due to the large number of animals held in a confined space to meet consumer demand; these animals may be caged, chained, or tethered. Confinement and lack of outdoor access often contribute to boredom and stress in animals, as they are unable to stretch, self-groom, or even turn their 
bodies, which results in physical and psychological distress (Overcash, 2011). Manure can often be found on animals and this waste is often the source of infectious bacteria, such as E. coli and Salmonella, which affect human populations through contaminated food and water, contributing further to disease (The PEw Charitable Trusts, 2008). This further adds to the use of more antibiotics for both humans and farm animals.

CAFOs are typically large, with at least 1,00o large animals, such as cattle bred for beef. By definition, a CAFO equals 1,00o head of beef cattle, 700 dairy cows, 2,500 swine weighing more than 55 pounds, 125,000 broiler chickens, or 82 thousand laying hens, confined to the site for over 45 days out of the year (USDA National Resources Conservation Services, n.d.). Most farmed animals spend their lives in these conditions. Approximately $98 \%$ of the meat in the us comes from CAFOs on an annual basis, including approximately 31 million cattle and calves, 120 million pigs, 450 million hen-laying chickens, 9 billion chickens raised for meat, and 250 million turkeys that are killed for human consumption (USDA National Agricultural Statistics Service, 2017; 2016). Industrialized factory farming of animals began in the Us over 50 years ago to increase efficiencies, and since then other countries have followed suit. In fact, the U K now has close to 800 mega farms, with similar concentrations and conditions to the US CAFOs (Wasley and Davies, 2017). The number of land animals killed for human consumption sheds light on the scale of global animal suffering, but the suffering does not end with land animals. The number of aquatic or sea animals killed for food each year is in the trillions, and whether farmed or caught from the wild, their suffering is often severe (Brooke and Mood, 2013). About $50 \%$ of the word's fish for consumption comes from fish farms (Food and Agriculture Organization of the United Nations, 2016). Much like CAFOs, the goal of maximizing profits leads to high density fish farms or aquaculture that are often breeding grounds for diseases that enter the water and the human food chain, requiring further research for antibiotics (McKeown and Halweil, 2009).

\subsection{Sustainability and Our Environment}

Plant-based diets are more environmentally sustainable and use fewer natural resources than diets based on animal products (Melina, Craig and Levin, 2016). Raising animals for food not only has significant impact on the suffering of animals, it has dire consequences for our environment as well. Worldwide, animal agriculture contributes to $14.5 \%$ of human-produced greenhouse gas emissions, which is more than all emissions from transportation, including planes, trains, and vehicles (Food and Agriculture Organization of the United Nations, 2013). In addition, pesticides, such as glyphosate, sprayed on crops fed to livestock are linked to water contamination. The world's demand for animal 
agriculture has resulted in the loss of pastures, including rainforests, to raise livestock. Industrial animal agriculture is the leading cause of overfishing, the destruction of wildlife, deforestation, and the depletion of freshwater resources (United Nations, n.d.). In addition, cattle ranching, due to deforestation, leads to carbon dioxide emissions, loss of biodiversity, soil degradation, and water pollution (Food and Agriculture Organization of the United Nations, n.d.). Growing crops to feed livestock is another burden on the environment. Global agriculture accounts for $30 \%$ of greenhouse gas emissions, with a high percentage from animal agriculture and the grains grown to raise them (USDA, 2010). In fact, a third of the world's cereal harvest is fed to factory farmed animals (Compassion in World Farming, 2017). Globally, we could potentially feed 3 billion people with these grains rather than raise animals to be killed for human consumption (Compassion in World Farming, 2017). In the Us, consumers eat more meat per capita than any other country in the world, and the hidden consequences of this consumption cost U $\$ 400$ billion a year, accounting for negative effects on the environment and human health (Simon, 2013a).

Discussions so far have presented a number of reasons for eating a plantbased diet-for health, including reducing antibiotic resistance, to support the environment, to reduce animal suffering, and reduce food insecurity. However, how do we transition to a more healthful diet that reduces the burden on animals used for experiments, and what are some of the major barriers to eating more healthfully? The following sections address what we can do at the individual level, the challenges we face at the systems, policy, and environmental levels, and how these challenges impact our individual choices to eat more health-promoting foods.

\section{5}

\section{Making the Shift}

\subsection{The Individual Level-Your Choices Matter}

Every day we make choices on what we eat. Are the foods we consume healthpromoting or disease-promoting? Making the choice to consume more health-promoting foods, particularly a whole foods, plant-based diet, with minimally processed or added sugar, increases our ability to control our own health. Eating more plant-based, whole foods can lead to improvements in blood pressure, cholesterol, and blood sugar and may lead to weight loss (Tuso et al., 2013). Addressing these risk factors with food as medicine can be a first line of defense against chronic diseases and may allow you to stave off or reduce the use of expensive life-long medications and/or invasive medical procedures. Individual choices also impact demand in our food supply. For example, consumer 
demand for plant-based milks has increased exponentially, and almond milk sales have grown by $250 \%$ in the past five years (Nielsen, 2016). In addition, $36 \%$ of American consumers prefer plant-based milks over traditional dairy (Nutrition Business Journal, 2015). In contrast, the traditional milk market has decreased by more than $\$ 1$ billion (Nielsen, 2016). In fact, the reduced demand for dairy has resulted in the us federal government purchasing a surplus of 11 million pounds of cheese for Us $\$ 20$ million, to feed participants enrolled in food assistance programs due to a 30-year high surplus (USDA, 2016).

The shift in consuming more plant-based foods is on the rise, especially among the millennial and $Z$ generations. In an age where younger generations have always had access to the internet and are accustomed to gaining information quickly, individuals are often more aware of the foods they eat. Among their top concerns about food are sustainability, animal welfare, and the healthfulness of food. Building awareness of where our food comes from and how it was produced is an important aspect of educating the masses. Being informed and making decisions on what you eat and how that impacts your personal health, animals, and the environment is empowering. At the individual level, the consumer can have an impact on reducing the need for animals in research on animal farming and testing of drugs for lifestyle-related diseases. Making a choice to purchase more whole plant-based foods puts money towards foods that are more sustainable, better for your health, and free of animal cruelty.

\section{Challenges to Healthful Eating}

Our diets have significantly changed over the past 50 years, and more so over the past 25 years, due to changes in farming practices and increased consumption of processed foods, meat, dairy, and eggs (Food and Agriculture Organization of the United Nations, 2017). At the same time, the number of animals used for disease research and the treatment of lifestyle-related diseases has also grown. We have choices in what we eat, but our choices are often influenced by a number of external factors.

\subsection{Advertising}

Food and beverage companies spend significant resources on promoting their products and often target children and adolescents. Research shows that advertising to children is an effective tactic to impact their food choices and attitudes towards food; and as most food advertising promotes unhealthy foods, its impact is negative. In 2012, the fast food industry spent Us $\$ 4.6$ billion 
on advertising, and children and teens were one of their primary audiences (Harris et al., 2013). Recent research from the Heart and Stroke Foundation of Canada reveals that "over $90 \%$ of food and beverage product ads viewed by kids and teens online are for unhealthy products, and collectively kids between the ages of 2 and 11 see 25 million food and beverage ads a year on their top 10 favorite websites" (Heart and Stroke Foundation of Canada, 2017, p. 8). Exposure to these advertisements may lead to an increase in poor food choices, possibly contributing to the development of obesity and chronic diseases.

\subsection{Funding Scientific Studies}

Large food corporations have large budgets for advertising and many also spend millions of dollars funding scientific research. Research has shown that industry sponsorship of studies often leads to bias in research outcomes (BesRastrollo et al., 2013). For example, The Coca-Cola Company funds scientists and organizations to promote physical activity, as the main driver to reducing obesity, rather than focusing on diet. Examples of funding recipients, include the National Parks and Recreation Association, Boys and Girls Club of America, and the Morehouse School of Medicine, Inc. (The Coca-Cola Company, n.d.). The Coca-Cola Company has also been known to use the influence of food industry representatives over scientific entities and medical associations to guide the debate in the interest of the food industry (Sacks, G. et al., 2017). Large food corporations provide funding to healthcare and nutrition focused organizations as well. By funding scientists and organizations, corporations influence research to focus on physical activity, for example, as the primary contributing factor in obesity rather than diet and healthful eating. A recent study found that 95 national health organizations in the Us, including medical and public health institutions that focus on obesity prevention, received funding from either The Coca-Cola Company or PepsiCo from 2011-2015 (Aaron and Siegel, 2017). The Academy of Nutrition and Dietetics, the Us's national association representing dieticians, has corporate sponsors, including CocaCola, Kraft Foods, Nestlé, Kellogg, the National Dairy Council, National Cattleman's Beef Association, ConAgra foods, and General Mills, many of which also provide continuing education credits for attending their educational sessions (Simon, 2013b). Corporate influence over healthcare organizations, scientists, and dieticians, in addition to the advertising and marketing of unhealthy foods, can influence the messages we receive from those we consider experts and lead to confusion about health-promoting foods, consequently, influencing our choices in favor of unhealthful foods.

Food companies have also been found to use animal experimentation to develop new ingredients or test the effectiveness of their food products in 
improving health. Animal experiments are conducted with the purpose of making health claims about their food products and generally result in ending animals' lives. Nestlé, Danone, and Yakult are among a few companies that have experimented on animals. Nestlé provides information to consumers on their approach to animal experimentation on their company website (Nestlé, n.d.). Major companies are also expanding their research approaches to include non-animal approaches to ensure consumer safety.

\subsection{Access to Healthy Food}

Unhealthy foods are profusely advertised in underserved populations, and research shows that people with lower socioeconomic status and communities of color are more likely to have access to an abundance of unhealthy fast foods and less access to healthy foods. Many of these communities are food deserts, where grocery stores or supermarkets are not in close proximity (PolicyLink and The Food Trust, 2013). Unfortunately, the grocery or corner stores in these neighborhoods often show a disparity in the quality, variety, quantity, and price of healthy foods they offer (PolicyLink and The Food Trust, 2013). For those receiving government funding, the us's Supplemental Nutrition Assistance Program (SNAP), formerly called food stamps, provides recipients with funds/credit to be used towards the purchase of food; and the SNAP programs pays retailers for the amount of food purchased. Currently, the SNAP program does not have a health focus, and funds can be used to purchase meat; dairy products; candy; energy drinks; and, essentially, any food product (USDA Food and Nutrition Services, 2017). Studies have shown that, in some cases, SNAP participants have worse diets and may be more likely to be obese than nonparticipants (Condon et al., 2015).

\subsection{Government and Food}

There are a multitude of initiatives focused on countering the obesity epidemic led by government funded surveillance and public health programs, nongovernment organizations, and healthcare organizations and their affiliates. Public health programs are not funded at the same the level as the food industry's programs, nor are they able to use government funds to lobby for better policies. Public health agencies dedicate significant resources to promote healthy behaviors, but the traditional food and beverage industries have much larger budgets to counteract these efforts. In 2016, food and beverage companies spent over US $\$ 31$ million on lobbying to establish legislation to protect or improve the sales of their products or to fight against legislation that could impact their bottom line (Center for Responsive Politics, 2016). 


\subsection{Subsidies}

The United States Department of Agriculture (USDA) leads public policy on food, agriculture, natural resources, rural development, nutrition, and related issues (USDA, n.d. a). The top focal areas of the USDA are to support farmers and ranchers, in addition to administering nutrition assistance programs, providing nutrition education, and creating dietary guidelines every five years, in conjunction with the United States Department of Health and Human Services (USDA, n.d. b). The multiple roles the USDA plays are often viewed with scrutiny, since the USDA creates guidelines on what Americans should eat, while supporting the promotion of and financial incentives for farmers of the commodities outlined in their dietary recommendations. For example, the USDA recommends the consumption of the following four food groups for a balanced diet: vegetables, fruits, grains, and proteins and three servings of dairy a day (ChooseMyPlate, n.d.). However, dairy products contain significant amounts of cholesterol and saturated fat, and cheese is the number one source of saturated fat in the American diet (National Cancer Institute Epidemiology and Genomics Research Program, n.d.; Physicians Committee for Responsible Medicine, n.d. b). There are a number of plant-based sources that have equivalent calcium to dairy, or even higher; and consumption of dairy has been shown to have little or no impact on bone health. Indeed, some studies have shown that increased dairy consumption is linked to increased fractures (Schooling, 2014). Furthermore, calcium needs can be met by eating plant-based foods instead (USDA Food Composition Databases, n.d.). The USDA also recommends choosing lean or low-fat meat and poultry and mentions that processed meats have added sodium; but it fails to mention that processed meats are considered a Group 1 carcinogenic food, linked to colorectal cancer; and that red meat was identified as a probable carcinogenic by the World Health Organization (World Health Organization International Agency for Research on Cancer, 2015). Red meat is also linked to increased rates of cardiovascular disease (Pan et al., 2012). Due to its close ties to major stakeholders (i.e., dairy, meat, and egg industries), the USDA would have to consider the economic impact of their actions should they deem these foods unnecessary for a healthy American diet. Recommendations for the Dietary Guidelines are made by researchers and experts in the field of nutrition, but the guidelines appear to include foods not present in these recommendations, such as some forms of dairy and meat (Heid, 2016). Although research supports a plant-forward or plant-based diet, the USDA is in a precarious position, since it is heavily influenced by lobbying (perhaps even data manipulation) by major stakeholders from the meat, dairy, and egg industries (Heid, 2016). 
Dairy and animal agriculture are among the commodities that receive the highest subsidies from the government. The us government provides subsidies to farmers and ranchers for commodity crops and livestock, with corn and soy at the top of the list. $63 \%$ of food subsidies support crops grown for feed or livestock, of which corn and soy are a major proportion (Physicians Committee for Responsible Medicine, n.d. a). About $20 \%$ of subsidies support grains for human consumption; $15 \%$ support crops, such as sugars, or crops that become sweeteners, starch, oil, and alcohol for human consumption; and $2 \%$ support fruits, vegetables, legumes, and nuts for human consumption (Physicians Committee for Responsible Medicine, n.d. a). This may seem alarming. More money is spent on subsidies to provide farm animals with feed or to raise livestock than for direct human consumption. Yes, that is correct. Furthermore, the dairy program alone received us $\$ 5.6$ billion in subsidies from 1995-2014 (Environmental Working Group, n.d.). Governmental subsidies saved the animal agriculture industry us $\$ 35$ billion from 1995-2005 (Physicians Committee for Responsible Medicine, n.d. a). The breakdown of subsidy allocation is significant because it reflects a misalignment between healthy eating guidance and financial government incentives. to support healthy eating by the government.

In the Us, all taxpayers contribute to subsidies that impact their health and environment and contribute to animal suffering. Around 20 billion in tax dollars are used annually to support agriculture subsidies and insurance, a bulk of which goes towards crops for livestock feed (us Government Accountability Office, 2017). Us taxpayers contribute to funding for animal experimentation as well. Approximately $47 \%$ of the research budget of the National Institutes of Health includes an animal experimentation component, which results in us $\$ 12$ billion-Us $\$ 14.5$ billion spent by taxpayers on animal experimentation annually (Pankevich et al., 2012). In addition to subsidies, the USDA oversees Research and Promotion programs, otherwise known as check-off programs, that support agriculture commodities voted on by farmers. These programs allow the government to use funding for private commercial goals, including advertising campaigns and research on the nutritional quality of agriculture commodities, without highlighting any particular producer or brand (National Agricultural Law Center, n.d.). The goal of these checkoff programs is to help improve the market position of chosen commodities by expanding markets, increasing demand, and developing new uses and markets (National Agricultural Law Center, n.d.). Examples of check-off programs include, "Got Milk?"; "Beef-It's What's for Dinner"; and "Pork, The Other White Meat." Research and promotion check-off programs fund the beef, milk, dairy, lamb, and poultry commodity groups, totaling approximately u $\$ 560$ million per year (Simon, 
2013a). Ultimately, the money spent on livestock research is for the purpose of increasing meat, dairy, and egg consumption.

\subsection{Policy Shifts}

Subsidies are not unique to the us, and similar programs providing financial incentives, especially for animal agriculture, exist in the European Union and Australia, among others. With the marketing efforts the food industry targets at children and adults, and the subsidies and indirect funds that animal agriculture receives to promote their products and protect their bottom line, the barriers to healthy eating are increasingly apparent. Animal products, such as meat, dairy, and eggs are artificially viewed as cheaper alternatives to plantbased foods, which are healthier and cause less harm to the environment or to animals. Subsidies should be re-visited to assess the need for these programs; and, if they are deemed necessary, they should align with more health promoting commodities used for human consumption. Some progress is being made, for example, the American Medical Association has called on the federal government to provide SNAP recipients with incentives for purchasing healthful foods, in an effort to improve their diets (Berg, 2017). SNAP retailers receive reimbursement for selling healthful foods but not for foods that promote disease. This shift could lead to more retailers stocking fresh produce, whole grains, beans, nuts, and seeds and healthy plant-based packaged foods. This call on the government should be further explored and implemented to improve access to healthful foods for SNAP recipients and underserved communities.

Creating a healthier food environment is an important step in improving access to healthy foods. Policies need to address widespread advertising of unhealthy foods, especially in lower income neighborhoods, while increasing the availability of healthful foods and creating healthier food standards for government assistance programs, such as SNAP and food pantries. In addition, the Dietary Guidelines should reflect current evidenced-based-research and include sustainable sources of food. The government should consider increasing support of farmers that grow plant-based crops, using sustainable farming practices, and offer support to farmers in declining animal agriculture industries to transition their skills, equipment, land, and training to farm plant-based crops, which are thriving, are considered health promoting foods, do not cause harm to animals, and are grown sustainably.

How we look at what constitutes as food is important. Based on centuries of research, we know that eating a diet rich in vegetables, fruits, whole grains, legumes, and nuts in small portions, is good for our health. The tobacco movement has had significant successes in raising awareness of its harmful health effects; and, with system and policy changes, such as implementing taxes on 
the sale of tobacco products, it has contributed to the decline in tobacco use. Though policy shifts are challenging to implement, and for tobacco these shifts took decades, the current foods systems across the globe may benefit from adopting proven strategies from the tobacco movement and tailoring them to combat lifestyle-related diseases. By removing subsidies for unhealthful foods, their true cost will be reflected in their price, which alone may create changes in purchasing behavior. The result of removing subsidies for, and possibly implementing taxes on, these foods could lead to a significant reduction in greenhouse gases, hundreds of thousands human lives saved each year from reductions in meat, dairy, and egg consumption (Nature Climate Change, 2016); as well as a reduction in the need for involving animals in research on agriculture and lifestyle-related diseases. In the meantime, individual lifestyle choices can go a long way to prevent the human, animal, and environmental harms caused by animal agriculture.

When we are ill, we visit our physician in hopes that they will provide a solution to fix our ailment. Physicians are seen as the go-to source when we are feeling unwell, and rightfully so; they are required to attend numerous years of schooling, pass extremely difficult qualifying exams, and undergo years of training, with long hours in residency and fellowship programs. Based on this extensive training, we assume that physicians are the best source for nutritional advice as well. The surprising fact is that most physicians receive very little nutrition education in their training (on average 20 hours or less) (Krebs and Primak, 2006). The lack of training they receive in medical school does not lend itself to using food as medicine or as the first line of treatment in combatting chronic diseases (Devries et al., 2014). Non-animal technologies, such as the organ on a chip, are contributing to the development of personalized medicine, which can benefit lifestyle disease research. In addition to nutrition training, we also need more training in animal-free research and development and in animalfree education and training (cf. e.g., Bones et al., 2019, Chapter 23; Herrmann, 2019, Chapter 1; Pawlowski et al., 2019, Chapter 22 in this Volume).

While physicians do not receive sufficient training in nutrition, they receive rigorous training in treating diseases with prescription medications in medical school and during their residency (Kshirsagar and Vu, 2016). Pharmaceutical companies reach out directly to physicians to market and provide education on their company's pharmaceutical drugs (Kshirsagar and Vu, 2016). This 
marketing entails gifts, sponsored lunches, promotional items, direct mailings, consultations, and samples. Many of the pharmaceutical companies spend more on marketing and promotion than on research and development. Research shows that marketing to physicians often results in an increase in their prescribing the promoted pharmaceuticals (Goodman, 2001). There has also been an increase in direct marketing to consumers by pharmaceutical companies (FDA, 2015). Policy reform should take into account the ethics of these practices, since consumers, like physicians, can be influenced by pharmaceutical marketing to seek out promoted medications that may not align with evidence-based science. What is more, the pharmaceutical industry is one of the main contributors to animal experimentation.

Since physicians are not traditionally trained in the use of a whole foods, plant-based diet to prevent or reverse disease, the status quo of prescribing medications to address symptoms or risk factors for a condition(s) continues. Physicians may have dieticians, nurses, health educators, or health coaches on staff that provide more in-depth nutrition education; but physicians should receive additional training on the benefits of eating a whole foods, plant-based diet to improve health. Increasing the requirements for nutrition education and ensuring physicians are paid for these efforts would be a step towards progress (Greger, 2013).

\section{A Plant-based Future}

This chapter provides a snapshot of our current food climate and how eating a whole foods, plant-based diet can help improve our health, reduce our demand for prescription drugs for lifestyle-related diseases, reduce the associated intensity of animal-based disease research (for human and agricultural diseases), avoid contributing to farm animal suffering, and protect our environment. Eating a whole foods, plant-based diet can save billions of dollars in personal healthcare costs, as well as costs associated with antibiotic resistance and disease research. It can reduce greenhouse gases and offset the grains used for livestock, to diversify crops and feed millions of people without food security.

Educating populations about the origins of our food and how the choices we make when deciding what goes in our mouth not only impacts our own bodies but the environment and billions of animals. That said, education must be associated with changes to policies and an environment that supports the production and distribution of health promoting foods. This should include 
removing subsidies for disease promoting foods, providing incentives to purchase health promoting foods, and creating environments where healthful foods are easily accessible.

To better serve our populations, physicians need more education and training on the role of nutrition in disease prevention while in medical school and through continued training in nutrition research. A shift is needed - the gold standard of using animals in identifying appropriate prescription drugs for humans must be revaluated and the focus must shift to advancing non-animal research methods that are more accurate and humanrelevant (Akhtar, 2015). Animal-free technologies that help develop personalized medicine should be encouraged as well. We must invest in human and clinical studies that reflect human responses to disease rather than relying on results from animal studies. Advocates for non-animal research methods need to continue to build awareness of the benefits and effectiveness of non-animal research and testing methods for helping those suffering from lifestyle-related diseases, while we continue our efforts to improve the population health of our nations.

At an individual level, by opting for a whole foods, plant-based diet, we can help reduce the need for new prescription drugs to treat illnesses and can benefit from advances in animal-free pathways for biomedical research to save animals, our health, the economy, and our environment.

\section{References}

Aaron, D.G. and M.B. Siegel (2017). Sponsorship of National Health Organizations by Two Major Soda Companies. American Journal of Preventive Medicine, 52(1), pp. 20-30. [online] Available at: https://www.ajpmonline.org/article/So749-3797(16)30331-2/ fulltext [Accessed 21 July 2017].

Agarwal, U., S. Mishra, J. Xu, S. Levin, J. Gonzales and N.D. Barnard (2015). A Multicenter Randomized Controlled Trial of a Nutrition Intervention Program in a Multiethnic Adult Population in The Corporate Setting Reduces Depression and Anxiety and Improves Quality of Life: The GEICO Study. American Journal of Health Promotion, 29(4), pp. 245-254.

Akhtar, A. (2015). The Flaws and Human Harms of Animal Experimentation. Cambridge Quarterly Healthcare Ethics, 24(4), pp. 407-419. [online]. Available at: https://www .cambridge.org/core/services/aop-cambridge-core/content/view/78DiF5E6B65 AE 7157B7AA85FF3Fo6017/Sog63180115000079a.pdf/flaws_and_human_harms_of _animal_experimentation.pdf [Accessed 29 June 2017]. 
Berg, S. (2017). AMA Backs Comprehensive Approach Targeting Sugary Drinks. American Medical Association (AMA) Wire. [online] Available at: https://wire.ama-assn .org/ama-news/ama-backs-comprehensive-approach-targeting-sugary-drinks [Accessed 24 August 2017].

Bes-Rastrollo, M., M.B. Schulze, M. Ruiz-Canela and M.A. Martinez-Gonzalez (2013). Financial Conflicts of Interest and Reporting Bias Regarding the Association Between Sugar-sweetened Beverages and Weight Gain: A Systematic Review of Systematic Reviews. PLoS Medicine, 10(12), p. e1001578 [online] Available at: http://journals. plos.org/plosmedicine/article?id=10.1371/journal.pmed.1001578 [Accessed 5 May 2018].

Bones, V.C., R.C.M. Garcia, G.G. Alves, R.L. Paixão, A.A. Rocha, K.V. Capilé and R. Bachinski (2019). Humane education: The tool for scientific revolution in Brazil. In: K. Herrmann and K. Jayne, eds., Animal Experimentation: Working Towards a Paradigm Change, Vol. 22. Location: Brill Human Animal Studies Series, pp. 567-582.

British Dietetic Association (2017). British Dietetic Association Confirms Well-planned Vegan Diets Can Support Healthy Living in People of all Ages. [online] Available at: https://www.bda.uk.com/news/view?id=179 [Accessed 27 August 2017].

Brooke, P. and A. Mood (2013). The Welfare of Fish in Commercial Fishing. [online] Available at: http://fishcount.org.uk/published/high/fishcount-presentation1-2013HR .pdf [Accessed 12 July 2017].

Carbone, L. (2004). What animals want: expertise and advocacy in laboratory animal welfare policy. New York, NY: Oxford University Press.

CDC (2016a). Multiple Chronic Conditions: Chronic Disease Prevention and Health Promotion. [online] Available at: https://www.cdc.gov/chronicdisease/about/multiple -chronic.htm [Accessed 13 July 2017].

CDC (2016b). Antibiotic Resistance: NARMS. [online] Available at: https://www.cdc .gov/narms/faq.html [Accessed 15 July 2017].

CDC (2016c). Burden of Foodborne Illness: Findings. [online] Available at: https://www .cdc.gov/foodborneburden/2011-foodborne-estimates.html [Accessed 20 July 2017].

CDC (2016d). Protecting the Food Supply: Antibiotic/Antimicrobial Resistance. [online] Available at: https://www.cdc.gov/drugresistance/protecting_food-supply.html [Accessed 12 July 2017].

CDC (2017a). Adult Obesity Facts: Overweight \& Obesity. [online] Available at: https:// www.cdc.gov/obesity/data/adult.html [Accessed 5 July 2017].

CDC (2017b). Chronic Disease Overview: Chronic Disease Prevention and Health Promotion. [online] Available at: https://www.cdc.gov/chronicdisease/overview/index .htm [Accessed 12 July 2017].

CDC (2017c). FastStats Obesity and Overweight. [online] Available at: https://www.cdc .gov/nchs/fastats/obesity-overweight.htm [Accessed 16 July 2017]. 
Center for Responsive Politics (2016). OpenSecrets: Lobbying Spending Database Food \& Beverage. [online] Available at: https://www.opensecrets.org/lobby/indusclient .php?id=No1\&year=2016 [Accessed 14 August 2017].

ChooseMyPlate (n.d.). MyPlate. [online] Available at: https://www.choosemyplate .gov/MyPlate [Accessed 22 July 2017].

Commonwealth Fund (2015). Us Spends More on Health Care Than Other High-income Nations but Has Lower Life Expectancy, Worse Health. [online] Available at: http:// www.commonwealthfund.org/publications/press-releases/2015/oct/us-spends -more-on-health-care-than-other-nations [Accessed 16 July 2017].

Compassion in World Farming (2017). Strategic Plan 2013-2017 for Kinder, Fairer Farming Worldwide. [online] Available at: https://www.ciwf.org.uk/media/3640540/ ciwf_strategic_plan_20132017.pdf [Accessed 11 July 2017].

Condon, E., S. Drilea, K. Jowers, C. Lichtenstein, J. Mabli, E. Madden and K. Niland (2015). Diet Quality of Americans by Snap Participation Status: Data from the National Health and Nutrition Examination Survey, 2007-2010. Walter R. McDonald \& Associates, Inc. and Mathematica Policy Research for the Food and Nutrition Service. [online] Available at: https://www.fns.usda.gov/sites/default/files/ops/NHANES -SNAPo7-10.pdf [Accessed 21 August, 2017].

Devries, S., J. Dalen, D. Eisenberg, V. Maizes, D. Ornish, A. Prasad, V.Sierpina, A. Weil and W. Willett (2014). A Deficiency of Nutrition Education in Medical Training. [online] Available at: http://dx.doi.org/10.1016/j.amjmed.2014.04.003 [Accessed 25July 2017].

Environmental Working Group (n.d.). EWG's Farm Subsidy Database - Dairy Program Subsidies in the United States Totaled \$5.6 Billion from 1995-2014. [online] Available at: https://farm.ewg.org/progdetail.php?fips=00ooo\&progcode=dairy [Accessed 23 July 2017].

Etemadi, A., R. Sinha, M.H. Ward, B.I. Graubard, M. Inoue-Choi, S.M. Dawsey and C.C. Abnet (2017). Mortality from Different Causes Associated with Meat, Heme Iron, Nitrates, and Nitrites in the NIH-AARP Diet and Health Study: Population-based Cohort Study. British Medical Journal, 357, j1957. [online] Available at: http://doi .org/10.1136/bmj.j1957 [Accessed 30 April 2018].

FDA (2014). Inside Clinical Trials: Testing Medical Products in People. [online] Available at: https://www.fda.gov/drugs/resourcesforyou/consumers/ucmi43531.htm [Accessed 13 July 2017].

FDA (2015). The Impact of Direct-to-consumer Advertising. [online] Available at: https://www.fda.gov/drugs/resourcesforyou/consumers/ucm143562.htm [Accessed 26 July 2017].

Food and Agriculture Organization of the United Nations (n.d.). Livestock Policy Brief o3: Cattle Ranching and Deforestation. Rome, Italy: Livestock Information, Sector Analysis, and Policy Branch (AGAL) of the Animal Production and Health Division 
of the Food and Agriculture Organization of the United Nations. [online] Available at: http://www.fao.org/3/a-a0262e.pdf [Accessed 11 July 2017].

Food and Agriculture Organization of the United Nations (2013). Tackling Climate Change Through Livestock. Rome, Italy: Food and Agriculture Organization of the United Nations. [online] Available at: http://www.fao.org/3/i3437e.pdf [Accessed 15 July 2017].

Food and Agriculture Organization of the United Nations (2014). Food and Agriculture Data. Rome, Italy: Food and Agriculture Organization of the United Nations. [online] Available: http://faostat.fao.org/ [Accessed 24 June 2017].

Food and Agriculture Organization of the United Nations (2016). The State of World Fisheries and Aquaculture 2016. Contributing to Food Security and Nutrition for all. Rome, Italy: Food and Agriculture Organization of the United Nations. [online] Available at: http://www.fao.org/3/a-i5555e.pdf [Accessed 5 July 2017].

Food and Agriculture Organization of the United Nations (2017). The Future of Food and Agriculture - Trends and Challenges. Rome, Italy: Food and Agriculture Organization of the United Nations. [online] Available at: http://www.fao.org/3/a-i6583e .pdf [Accessed 22 July 2017].

Goodman, B. (2001). Do Drug Company Promotions Influence Physician Behavior? [online] Available at: https://www.ncbi.nlm.nih.gov/pmc/articles/PMC1071337/ [Accessed 1 August 2017].

Greek, R., A. Menache and M.J. Rice (2012). Animal Models in an Age of Personalized Medicine. Personalized Medicine, 9(1), pp. 47-64. [online] Available at: https://do i.org/10.2217/pme.11.89 [Accessed 13 April 2018].

Greger, M. (2013). Lifestyle Medicine: Treating the Causes of Disease. NutritionFacts.org. [online] Available at: https://nutritionfacts.org/video/lifestyle-medicine-treating -the-causes-of-disease/ [Accessed 25July 2017].

Harris, J., M. Schwartz, C. Munsell, C. Dembek, S. Liu, M. LoDolce, A. Heard, F. Fleming-Milici and B. Kidd (2013). Fast food FACTS 2013: Measuring Progress in Nutrition and Marketing to Children and Teens. Yale University Rudd Center for Food Policy \& Obesity. [online] p. vi. Available at: http://www.fastfoodmarketing.org/media /FastFoodFACTS_Report.pdf [Accessed 23 August 2017].

Heart and Stroke Foundation of Canada (2017). The Kids Are Not Alright. How the Food and Beverage Industry Is Marketing Our Children and Youth to Death. 2017 Report on the Health of Canadians. [online] p. 8. Available at: https://www .heartandstroke.ca/-/media/pdf-files/canada/2017-heart-month/heartandstroke -reportonhealth2017.ashx [Accessed 18 July 2017].

Heid, M. (2016). Experts Say Lobbying Skewed the U.S. Dietary Guidelines. Time Health. [online] Available at: http://time.com/4130043/lobbying-politics-dietaryguidelines [Accessed 30 April 2018]. 
Herrmann, K. (2019). Refinement on the way towards Replacement: Are we doing what we can? In: K. Herrmann and K. Jayne, eds., Animal Experimentation: Working Towards a Paradigm Change, Vol. 22. Brill Human Animal Studies Series, pp.3-64. Leiden: Brill.

Keen, J. (2019). Wasted money in US biomedical and agricultural animal research. In: K. Herrmann and K. Jayne, eds., Animal Experimentation: Working Towards a Paradigm Change, Vol. 22. Brill Human Animal Studies Series, pp. 244-272. Leiden: Brill.

Krebs, N. and L. Primak (2006). Comprehensive Integration of Nutrition into Medical Training. The American Journal of Clinical Nutrition, 83(4), pp. 945S-95oS [online] Available at: https://doi.org/10.1093/ajcn/83.4.945S [Accessed 13 April 2018].

Kshirsagar, R. and P. Vu (2016). The Pharmaceutical Industry's Role in Us Medical Education. [online]. Available at: http://in-training.org/drugged-greed-pharmaceuticalindustrys-role-us-medical-education-10639 [Accessed 1 August 2017].

Light, D.W. (2014). New Prescription Drugs: A Major Health Risk With Few Offsetting Advantages. Harvard University Edmond J Safra Centre of Ethics. [blog] Available at: https://ethics.harvard.edu/blog/new-prescription-drugs-major-health-risk-fewoffsetting-advantages [Accessed 30 July 2018].

Malhotra, A., T. Noakes, and S. Phinney (2015). It Is Time to Bust the Myth of Physical Inactivity and Obesity: You Cannot Outrun a Bad Diet. British Journal of Sports Medicine, 49, pp. 967-968. [online] Available at: http://dx.doi.org/10.1136 /bjsports-2015-094911 [Accessed 02 July 2017].

McKeown, A. and B. Halweil (2009). Vital signs 2009. Washington DC: WorldWatch Institute, p. 22.

Melina, V., W. Craig and S. Levin (2016). Position of the Academy of Nutrition and Dietetics: Vegetarian Diets. [online] Available at: http://jandonline.org/article/S22122672\%2816\%2931192-3/fulltext [Accessed 10 August 2017].

National Agricultural Law Center (n.d.). Checkoff Programs. [online] Available at: http://nationalaglawcenter.org/research-by-topic/checkoff-programs/ [Accessed 24July 2017].

National Cancer Institute Division of Cancer Control and Population Sciences. (n.d). Table 1. Top sources of Saturated Fat Among U.S. Population, 2005-2006 NHANES [online] Availableat:https://epi.grants.cancer.gov/diet/foodsources/sat_fat/sf.html [Accessed 26 July 2017].

National Institute on Drug Abuse (2017). Opioids. [online] Available at: https://www .drugabuse.gov/drugs-abuse/opioids [Accessed 14 July 2017].

Nature Climate Change (2016). Mitigation Potential and Global Health Impacts from Emissions Pricing of Food Commodities. [online] Available at: https://www .nature.com/nclimate/journal/v7/n1/full/nclimate3155.html [Accessed 25 July 2017]. 
Nestlé (n.d.). Do You Test Your Products on Animals? [online] Available at: https://www .nestle.com/ask-nestle/products-brands/answers/do-you-test-your-products -on-animals [Accessed 15 August 2017].

Nielsen (2016). Americans Are Nuts for Almond Milk. [online] Available at: http://www .nielsen.com/us/en/insights/news/2016/americans-are-nuts-for-almond-milk.html [Accessed 9 July 2017].

Nutrition Business Journal (2015). 2015 Food Tribes Report. [online] Available at: https:// www.prnewswire.com/news-releases/nutrition-business-journal-announces-the2015-food-tribes-report-300073987.html [Accessed 9 July 2017].

Overcash, E. (2011). Animal Legal \& Historical Center: Overview of CAFOs and Animal Welfare Measures. Animallaw.info [online] Available at: https://www .animallaw.info/article/overview-cafos-and-animal-welfare-measures [Accessed 18 July 2017].

Pan, A., Q. Sun, A.M. Bernstein, M.B. Schulze, J.E. Manson, M.J. Stampfer, W.C. Willett and F.B. Hu (2012). Red Meat Consumption and Mortality: Results from 2 Prospective Cohort Studies. Archives of Internal Medicine, 172(7), pp. 555-563 [online] Available at: https://www.ncbi.nlm.nih.gov/pmc/articles/PMC3712342/ [Accessed 10 August 2017].

Pankevich, D., T. Wizemann, A. Mazza and B. Altevogt (2012). International Animal Research Regulations: Impact on Neuroscience Research. Workshop Summary. Washington, DC: National Academies Press, IOM Institute for Laboratory Animal Research. [online] Available at: https://www.ncbi.nlm.nih.gov/books/NBK1oo123/ [Accessed 18 July 2018].

Pawlowski, J., D. Feinstein, M.L. Crandall and S. Gala (2019). Modernizing biomedical training: Replacing live animal laboratories with human simulation. In: K. Herrmann and K. Jayne, eds., Animal Experimentation: Working Towards a Paradigm Change, Vol. 22. Brill Human Animal Studies Series, pp. 551-566. Leiden: Brill.

Physicians Committee for Responsible Medicine (n.d. a). Agriculture and Health Policies in Conflict: How Subsidies Tax Our Health. [online] Available at: http:// www.pcrm.org/health/reports/agriculture-and-health-policies-ag-versus -health [Accessed 24 July 2017].

Physicians Committee for Responsible Medicine (n.d. b). Health Concerns About Dairy Products. [online] Available at: http://www.pcrm.org/health/diets/vegdiets/healthconcerns-about-dairy-products [Accessed 23 July 2017].

PolicyLink and The Food Trust (2013). Access to Healthy Food and Why It Matters: A Review of the Research. [online] Available at:http://www.policylink.org/find-resources/ library/access-to-healthy-food-and-why-it-matters [Accessed 23 July 2017].

Rudd, R., P. Seth, F. David and L. Scholl (2016). Increases in Drug and Opioid-involved Overdose Deaths-United States, 2010-2015. MMWR Morbidity Mortality Weekly, Rep 2016, 65, pp. 1445-1452. 
Sacks, G. B. Swinburn, A. Cameron and G. Ruskin (2017). How Food Companies Influence Evidence and Opinion-Straight from the Horse's Mouth, Critical Public Health, 28(2), pp. 253-256, [Online] Available at: Https://Doi.Org/10.1080/09581596 .2017.1371844 [Accessed 13 April 2018].

Sarkar, U., A. López, J.H. Maselli and R. Gonzales (2011). Adverse Drug Events in US Adult Ambulatory Medical Care. Health Services Research, 46, pp. 1517-1533. Available at: https://www.ncbi.nlm.nih.gov/pmc/articles/PMC3168717/.

Schooling, C. (2014). Milk and Mortality. [online] Available at: https://doi.org/10.1136/ bmj.g6205 [Accessed 23 July 2017].

Shanks, N., R. Greek and J. Greek (2009). Are Animal Models Predictive for Humans? Philosophy, Ethics, and Humanities in Medicine, 4(2). [online] Available at: https:// doi.org/10.1186/1747-5341-4-2 [Accessed 28 June 2017].

Simon, D.R. (2013a). Meatonomics: How the Rigged Economics of Meat and Dairy Make You Consume Too Much - and How to Eat Better, Live Longer, and Spend Smarter. Newburyport, MA: Conari Press.

Simon, M. (2013b). And Now a Word from Our Sponsors: Are America's Nutrition Professionals in the Pocket of Big Food? EatDrinkPolitics. [online] Available at: http://www .eatdrinkpolitics.com/wp-content/uploads/AND_Corporate_Sponsorship_Report .pdf [Accessed 22 July 2017].

Specialist Pharmacy Service (2014). Medicines Related Problems on Admission: The Evidence. Specialist Pharmacy Service-The First Stop for Professional Medicines Advice. [online] Available at: https://www.sps.nhs.uk/articles/medicines-relatedproblems-on-admission-the-evidence/ [Accessed 15 July 2017].

The Coca-Cola Company (n.d.). Our Commitment To transparency. [online] Available at: http://transparency.coca-colacompany.com/our-commitment-transparency [Accessed 21 July 2017].

The GBD 2015 Obesity Collaborators (2017). Health Effects of Overweight and Obesity in 195 Countries Over 25 Years. New England Journal of Medicine. 377, pp. 13-27. [online] Available at: http://www.nejm.org/doi/full/10.1056/NEJMoa1614362 [Accessed 15 July 2017].

The PEW Charitable Trusts (2008). Putting Meat on the Table: Industrial Farm Animal Production in America. [online] Available at: http://www.pewtrusts.org/ /media/ legacy/uploadedfiles/peg/publications/report/pcifapfinalpdf.pdf [Accessed 2o July 2017].

Tuso, P., M. Ismail, B. Ha and C. Bartolotto (2013). Nutritional Update for Physicians: Plant-based Diets, The Permanente Journal 2013, 17(2), pp. 61-66. [online] Available at: https://doi.org/10.7812/TPP/12-085 [Accessed 29 June 2017].

United Nations (n.d.). Overfishing: A Threat to Marine Biodiversity. [online] Available at: http://www.un.org/events/tenstories/o6/story.asp?storyID=80o [Accessed 14 July 2017]. 
US Department of Health and Human Services, Foodsafety.gov (n.d.). Home. [online] Available at: http://Foodsafety.gov [Accessed 10 July 2017].

US Government Accountability Office (2017). Key Issues: Farm Programs. [online] Available at: https://www.gao.gov/key_issues/farm_programs/issue_summary [Accessed 24 July 2017].

USDA (n.d. a) About the Us Department of Agriculture. [online] Available at: https:// www.usda.gov/our-agency/about-usda [Accessed 20 July 2017].

USDA (n.d. b) Mission Areas. [online] Available at: https://www.usda.gov/our-agency/ about-usda/mission-areas [Accessed 22 July 2017].

USDA (2010). Climate Change Science Plan. The Climate Change Program Office. [online] Available at: https://www.usda.gov/oce/climate_change/science_plan2010/ USDA_CCSPlan_120810.pdf [Accessed 12 July 2017].

USDA (2016). USDA to Purchase Surplus Cheese for Food Banks and Families in Need, Continue to Assist Dairy Producers. [online] Available at: https://www.fsa.usda .gov/news-room/news-releases/2016/nr_20160823_rel_0181 [Accessed 26 August 2017].

USDA Agricultural Research Service (n.d.). Us Meat Animal Research Center. [online] Available at: https://www.ars.usda.gov/plains-area/clay-center-ne/marc/ [Accessed 6 July 2017].

USDA Food and Nutrition Services (2017). Supplemental Nutrition Assistance Program (SNAP) Eligible Food Items. Food and Nutrition Service. [online] Available at: https://www.fns.usda.gov/snap/eligible-food-items [Accessed 22 August 2017].

USDA Food Composition Databases (n.d.). Food Composition Databases Show Nutrients List. [online] Available at: https://ndb.nal.usda.gov/ndb/nutrients/\%2oreport ?nutrient $1=301 \&$ nutrient $2=\&$ nutrient $3 \% 20=\&$ fg $=11 \& \% 20$ max $=25 \&$ subset $=1 \&$ offset $=125 \&$ sort $=$ f\& $\&$ totCount $=134 \&$ measureby $=m$ [Accessed 24 August 2017].

USDA National Agricultural Statistics Service (2016). Overview of the United States Slaughter Industry. (2016). [online] Available at: http://usda.mannlib.cornell .edu/usda/current/SlauOverview/SlauOverview-10-27-2016.pdf [Accessed 20 July 2017].

USDA National Agricultural Statistics Service (2017). Livestock Slaughter 2016 Summary. Agricultural Statistics Board. [online] Available at: http://usda.mannlib .cornell.edu/usda/current/LiveSlauSu/LiveSlauSu-04-19-2017.pdf [Accessed 20 July 2017].

USDA National Resources Conservation Services (n.d.). Animal Feeding Operations. [online] Available at: https://www.nrcs.usda.gov/wps/portal/nrcs/main/national/ plantsanimals/livestock/afo/ [Accessed 18 July 2017].

Wasley, A., M. Davies (2017). The Rise of the "Megafarm": How British Meat Is Made. The Bureau of Investigative Journalism. [online] Available at: https://www 
.thebureauinvestigates.com/stories/2017-07-17/megafarms-uk-intensive-farming -meat [Accessed 17 July 2017].

World Health Organization International Agency for Research on Cancer (2015). IARC Monographs evaluate consumption of red meat and processed meat. Lyon, France. [online] Available at: http://www.iarc.fr/en/media-centre/pr/2015/pdfs/pr240_E .pdf [Accessed 23 July 2017]. 